\title{
Agrarian change and diversity in the light of Brookfield, Boserup and Malthus: Historical illustrations from Sulawesi, Indonesia
}

\author{
David Henley \\ Royal Netherlands Institute of Southeast Asian and Caribbean Studies (KITLV), \\ Postbus 9515, 2300 RA Leiden, Netherlands. \\ Email: henley@kitlv.nl
}

\begin{abstract}
This paper uses historical sources to examine the relationship between demography, economy and ecology in three parts of the island of Sulawesi (Indonesia) over a long time period. Broadly speaking, these case studies suggest both the density of population and the intensity of agricultural activity at any given time and place were controlled by two factors. The first was the agricultural potential of the natural environment in terms of soil, climate and topography: populations were denser, and farming more area-intensive, in naturally fertile areas. The second was the extent to which the local economy was commercialised rather than subsistence-oriented: when commerce grew, so did both the population and the intensity of its farming systems. In terms of ecological sustainability and resilience, densely populated enclaves of intensive, commercialised agriculture tended to perform better than did sparsely populated and economically isolated areas of subsistence production, where progressive deforestation and land degradation sometimes occurred. Although one reason for this was simply that the former were located on better soils than the latter, other reasons included the greater use of tree crops, and the greater availability of labour for investment in what Brookfield called 'landesque capital', which characterised the more populous and commercialised areas.
\end{abstract}

Keywords: land use, agriculture, intensification, sustainability, demography, agroforestry, irrigation

This paper deals with the relationship between demography, economy and ecology in the history of one part of the Asia-Pacific region before the onset of industrialisation, the Green Revolution, or modern medicine and birth control. In doing so it draws on two mutually related aspects of Harold Brookfield's work: his exegesis and critique of the theory of agricultural intensification (1972, 1984, 2001b), and his ideas regarding the preconditions for sustainable and resilient smallholder agriculture (Blaikie and Brookfield, 1987; Brookfield, 2001a).

\section{Brookfield, Boserup and Malthus}

In his early work on agricultural intensification Brookfield, like many others, was strongly inspired by the 'population-based theory of intensification' proposed by Ester Boserup (1965). This theory concentrated particularly on the role of labour (rather than capital or technical) inputs.
Pre-industrial farmers, according to the Boserup model, were almost always technically capable of increasing the productivity of their land by applying methods (soil tillage, additional weeding, application of organic fertilisers and irrigation) which allowed it to be cropped more frequently and fallowed for shorter periods. But because such methods typically demanded higher labour inputs per unit of production, they tended to be adopted only when population pressure and the resulting land scarcity forced farmers to work harder in order to maintain existing levels of subsistence.

When a piece of land is to be cropped more frequently - under pre-industrial techniques it will usually be necessary to devote more agricultural labour to each crop hectare than before. [...] It is suggested, furthermore, that, in the typical case, an intensification of the pattern of land use reduces output per man-hour, or, in other words, that agricultural employment 
increases at a higher rate than agricultural output, when there is a transition to a more intensive kind of land utilization under the pressure of population growth. (Boserup, 1965: 43)

'Although criticised and faulted', concludes Brookfield (2001b: 181) in a recent overview, 'that model has become almost orthodoxy since the 1980s'. In writings dealing with South-East Asia, certainly, the interpretation of agricultural intensification as resulting directly (if seldom exclusively) from population growth has been common over the last two decades. ${ }^{1}$ In the Indonesian context, Boserup's work ultimately also underpins the influential idea that wet rice cultivation and other area-efficient forms of agriculture tend to reflect the forcible concentration of formerly dispersed swidden-farming populations by predatory states intent on controlling and taxing them (Dove, 1985) or stealing their land (Potter, 2001).

Yet at the same time, some South-East Asianists have raised important doubts regarding the empirical relevance of the Boserup model. In the first place there is the suspicion - also growing, as Brookfield (2001b: 182) emphasises, in the literature on other parts of the world - that although they have often coincided with population growth, episodes of agricultural intensification have more often been inspired by price incentives to surplus production than by the necessity of maintaining subsistence production at existing levels under conditions of increasing land scarcity.

Whether population growth caused people to develop their production systems in the way that they did or whether it merely facilitated their seizure of a particular set of opportunities is a question that cannot be answered readily. [...] Farmers pay close attention to market signals and change their land use accordingly. It is certainly easier to see this happen than to see quick response to perception of decline in the marginal product of additional labor, on which the Boserup trigger relies. (Brookfield, 2001a: 215).

In a study of agriculture and population pressure on Flores in the 1970s, Metzner (1982: 205) found that although labour-intensive intercropping techniques had allowed unirrigated farmland to support a rapidly increasing pop- ulation at surprisingly high densities, quantitative variations in the labour-intensity of agriculture from place to place were correlated less with population density itself than with the degree to which the local economy was 'commercialised'. Scholz (1988: 215), in a comprehensive agrarian geography of Sumatra in the 1980s, agreed that recent trends towards both irrigated rice farming and intensive planting of perennial crops' had been 'the result of the invading money economy rather than of population pressure $^{\prime 2}$

A second problem with the Boserup model is that even when a direct correlation can indeed be detected between agricultural intensity and population density, there are often serious doubts regarding the direction of the causality involved. Instead of demographic growth leading to intensification, Allen (2001: 239) and Booth (1991: 43; 1998: 248) have pointed out, it might equally be intensification, by means of growth in the agricultural output per unit area of land, which leads the population density to increase. The underlying dynamic, in other words, may be Malthusian (production growth causes population growth) rather than Boserupian (population growth causes production growth). ${ }^{3}$ Both Booth and Allen are inclined to see migration from less to more productive areas as the mechanism by which this adjustment has most often taken place. ${ }^{4}$ A more radical interpretation is that variations in what may loosely be called the demographic 'carrying capacity' of local economic systems have exerted in situ control over local population densities by affecting mortality and/or fertility rates. ${ }^{5}$ One obvious pointer in this direction is the close and persistent geographical correlation which exists within Indonesia between settlement density and soil quality. ${ }^{6}$ The rural population of the Indonesian archipelago has always been heavily concentrated in those areas - in the first place, Central and East Java - where ash from active volcanoes and/or a relatively pronounced annual dry season counteract the rapid leaching of soil nutrients characteristic of the humid tropics. ${ }^{7}$ The sheer geographical scale of this association already makes it very difficult to believe that the persistently sparse settlement of nonvolcanic, ever-wet areas in lowland Sumatra, Kalimantan and New Guinea has resulted from constant emigration of surplus population rather 
than from in situ constraints on demographic growth.

A third challenge to Boserupian intensification theory in the South-East Asian context comes from mounting evidence that the conventional contrast between labour-efficient swidden rice farming on the one hand, and labour-intensive (but area-efficient) wet rice cultivation on the other, is overdrawn or even misleading. In an early comparison of field studies from several parts of the region, Hanks (1972: 64) already showed that although wet rice growers did tend to work a greater total amount of time in their fields than did swidden farmers, in many cases their labour was also more productive. Wet rice farmers who sowed their seed by direct broadcasting, in fact, produced up to twice as much rice as swidden cultivators for each day of work performed. Padoch (1985: $282,286)$ later found that under the favourable topographic and soil conditions provided by some upland valleys in Kalimantan, irrigation was more labour-efficient than swiddening even when wet rice farmers used the more laborious technique of transplanting seedlings from nursery beds. Recently, Hunt (2000) has reconsidered the relevant South-East Asian evidence and concluded that according to all field studies which permit rigorous comparison in this respect, irrigated farming is actually more productive than swiddening in terms of rice yields per person-day of routine cultivation labour inputs. None of these comparisons, it must be said, takes into account non-rice crops (often a particularly important factor in swidden farming), livestock (for instance, the upkeep of plough animals), or (most crucially) the initial labour investments needed to create irrigation and pond-field infrastructure. Nevertheless, there are clearly strong grounds for caution regarding the Boserupian assumption that the adoption of wet rice cultivation has always reflected a sacrifice of labour-efficiency for the sake of area-efficiency. ${ }^{8}$

If some of its most central elements have come under increasing attack, one aspect of the Boserup model which has stood up better against the South-East Asian evidence is its optimism regarding the capacity of smallholder agriculture, with the help of labourintensification and low-technology innovations, to support rapidly growing populations without causing permanent land degradation.
It has no doubt happened [...] that a population, faced with a critically increasing density was without knowledge of any types of fertilization techniques. They might then shorten the period of fallow without any other changes in methods. This constellation would typically lead to a decline of crop yields and sometimes to an exhaustion of land resources. [...] We know, however, that many different methods of fertilization have been in use all over the world since very ancient times. It must have happened frequently that one people could learn from neighbours [...] how to preserve crop yields with shorter periods of fallow than those they had used hitherto. (Boserup, 1965: 41)

Since the 1960s the realisation has grown that it is not always necessary for would-be intensifiers to have contacts with groups already practising intensive agriculture in order to acquire the necessary technology; even such apparently major innovations as irrigation and terracing have probably been developed independently, by processes of trial and error, in many times and places. $^{9}$

It is unwise to assume that the idea of terrac-
ing has to be imported to an area where peo-
ple were previously ignorant of this technol-
ogy. Terracing, like diverting water to bring it to
places where it is needed, is a commonsense
adaptation to local needs and conditions. These
practices have arisen spontaneously in many ar-
eas. (Brookfield, 2001a: 170)

Whether or not such innovations are directly induced by declining yields from existing systems, as Boserup supposed, or by market incentives to raise yields, as Brookfield and others suggest, it is a fact that they serve to maintain, or even enhance, agricultural sustainability. The sustainability of the South-East Asian irrigated ricefield (Indonesian: sawah) as an ecosystem has long been appreciated. In his seminal book Agricultural Involution, Geertz (1963: 29) made much of 'its extraordinary stability and durability, the degree to which it can continue to produce, year after year, and often twice in 1 year, a virtually undiminished yield'.

Regarding the prospects for agricultural intensification in those parts of Indonesia where soil and topographic conditions did not favour irrigation, Geertz was much less sanguine. Many 
mid-twentieth century publications on swidden farming in South-East Asia contain dire warnings about the (actual or anticipated) transgression of critical population densities, and the creation of 'green deserts' of sword grass on land exhausted by itinerant mangeurs de bois. ${ }^{10}$ The most stable and benign systems of unirrigated agriculture on poor soils were then often thought to be those found in certain remote tribal areas little affected by either population growth or commerce, where long fallow periods permitted the regrowth of seminatural woodland vegetation between cultivation cycles. ${ }^{11}$ Today, however, there is general appreciation - reflected in, and stimulated by, the work of Harold Brookfield (1993: 370; 2001a: 145-151) - for the role of arboricultural or 'agroforestry' practices based on commercial tree products (including copra, rubber, resins and in some areas also fruits, timber and firewood for local markets) in promoting sustainable land management, often as direct developments of swidden farming or in close association with it. ${ }^{12}$ By allowing farmers to profit from the biomass-generating heat and humidity of the equatorial environment without making unsustainable demands on its mostly infertile soils, the modern commercial demand for tree crops has enabled South-East Asian agriculture to overcome ecological obstacles which once restricted it to either intensive wet rice cultivation in particularly favourable locations or the production of annual foodcrops in temporary swiddens (Scholz, 1984: 366; 1991: 49-51).

Cases of sustained land degradation as a result of intensive cash cropping by small farmers continue to be documented from Indonesia and neighbouring countries in the specific context of commercial vegetable production on upland slopes. ${ }^{13}$ In general, however, scholarly views on the conditions for sustainability in South-East Asian smallholder (as opposed to plantation) agriculture have tended to come into line with those of writers dealing with other parts of the world, particularly tropical Africa, who argue that both population growth and commercialisation often promote sustainable rather than unsustainable land use. ${ }^{14}$ One of the mechanisms involved here is the creation or opening up of markets for a broader range of farm products, including tree crops. Another is an increase in the per hectare availability of labour and capital for long-term investments such as tree planting and terrace construction - that is, investments in what Blaikie and Brookfield (1987: 9) seminally term 'landesque capital'. A further factor is the consolidation of permanent individual land ownership rights which often takes place as a more or less spontaneous process when land values rise, and which is conducive to long-term agrarian investments. ${ }^{15}$

\section{Northern Sulawesi, 1850-1950: Three farming systems and their evolution}

Northern (North and Central) Sulawesi is a rugged and geographically complex region covering a land area of roughly 90000 square kilometres and stretching over a maximum straightline distance (from Palu to Talaud) of more than $1000 \mathrm{~km}$. In the middle of the nineteenth century its inhabitants, then perhaps 700000 people in total, were mostly farmers growing subsistence crops on swidden fields, fishing (and occasionally hunting) to supplement their diet and obtaining the limited quantity of trade goods which they consumed (principally textiles and iron) by selling coconut oil, cacao, coffee, surplus rice, or gold dust and forest products collected during the agricultural off-season. ${ }^{16}$ In what follows a brief comparison is sketched between three historically rather well-documented areas within this region: the drainage basin of the Poso river and the lake in the heart of Central Sulawesi; the plateau of Minahasa at the tip of the northern peninsula; and the Sangir islands between Sulawesi and Mindanao (Philippines) in the far north (see Fig. 1). With respect to the period between (roughly) 1850 and 1950, the salient characteristics of the three areas can be summarised as shown in Table 1.

This (admittedly limited) selection of data suggests that variations in both population density and the extent of involvement in commerce were correlated, on a geographical basis, with variations in soil fertility. In general the level of sustainability in land use was also positively correlated not only with soil quality, but also with population density and production for commerce: land degradation was found in the area where the population was sparse rather than dense, and where the economy was isolated rather than open. The two more populous, economically developed settings, Minahasa and Sangir, featured two very different types of 
Agrarian change and diversity

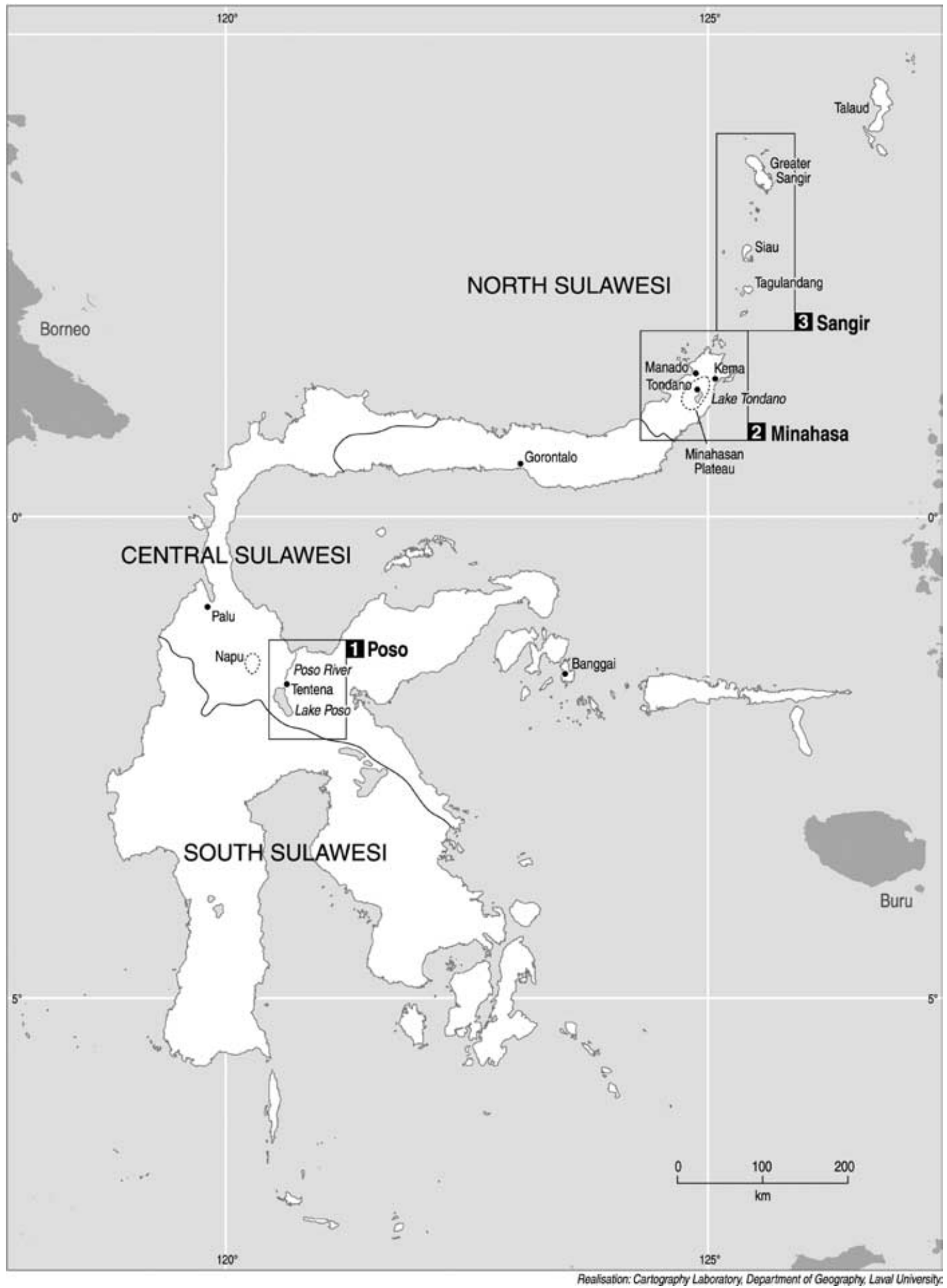

Figure 1. Sulawesi (Indonesia) showing location of study areas 
Table 1. Selected characteristics of the three study areas

\begin{tabular}{llll}
\hline & \multicolumn{1}{c}{ Poso } & Minahasa & Sangir \\
\hline Soil fertility & Low & High & High \\
Characteristic agriculture & Swidden farming & Wet rice cultivation & Agroforestry \\
Population density & Low and falling & High and rising & High and rising \\
Level of commercialisation & Low and falling & High & High and rising \\
Progressive deforestation & Yes & Yes & No \\
Land degradation & Yes & No & No \\
\hline
\end{tabular}

intensive, sustainable agriculture: wet rice cultivation and commercial agroforestry, respectively. In the isolated, non-commercial setting, Poso, it was itinerant (as opposed to rotational) shifting cultivation which led to progressive deforestation and land degradation.

\section{Poso}

At one extreme on the environmental, demographic and economic spectrum, then, lay the infertile, sparsely populated and economically isolated environs of Lake Poso. Here the most widespread soils were acidic types developed on ultrabasic parent materials, which are notoriously difficult to cultivate wherever they occur (RePPProT, 1990: 148), and shallow calcareous soils, which are porous and highly susceptible to erosion under Indonesian conditions (Dames, 1955: 95; Hardjono, 1971: 94). The average population density in the Poso depression around 1850 did not exceed beyond 15 persons per square kilometre, while the local economy was only weakly commercialised, with no regular marketplaces and little circulating cash (Adriani and Kruyt, 1912-1914, I: 89; II: 299312). The main exports were limited quantities of wild forest products like rattan, beeswax and damar (conifer resin). Foodcrop agriculture, as in many other parts of the region, was based on rice and maize grown exclusively on dry swidden fields. The reported fallow period, at 6-8 years (Kruyt, 1895-1897, II: 117), was also unexceptional. Here, however, this rotation was apparently unsustainable: unusually in northern Sulawesi, soils and/or fallow vegetation frequently became so degraded that whole villages, and not just their outlying swidden huts, were obliged to shift to new locations. ${ }^{17}$ Part of the abandoned land provided grazing for deer and semidomesticated water buffalo, becoming grassland or savanna which was periodically set on fire in order to promote the growth of young grass shoots for that purpose (Figs 2,3). ${ }^{18}$

In the valley of one tributary of the Poso river, the progressive expansion of fire-climax grasslands led to sustained emigration towards the end of the nineteenth century in connection with what missionary-anthropologist Albert Kruyt (1899: 608), despite his insistence elsewhere (1903: 191) that this part of Central Sulawesi was sparsely populated, described as 'overpopulation and the resulting lack of arable land'. In another grassy valley to the east of Lake Poso where the sites of several abandoned villages were to be found, local people reported that no maize would grow because of a curse which had afflicted the once fertile soil (Adriani and Kruyt, 1912-1914, I: 54). There are indications, in fact, that the total population of the Poso depression declined during the second half of the nineteenth century (Kruyt, 1903: 203-204) and probably also over a much longer timespan (Henley, 2005: 228-229). This trend can probably be explained partly in terms of a structural decline in the carrying capacity of local agriculture due to land degradation. Another likely factor is that at the period of denser population, the local economy had been more commercialised, permitting imports of agricultural and other produce which were later cut off. Parts of the Poso area were once important sources of iron ore, weapons forged from which were exported by means of the east coast of Central Sulawesi to other parts of Indonesia. ${ }^{19}$ Beginning in the seventeenth century and continuing up to the twentieth, this industry gradually declined due to competition from iron imported to Indonesia from Europe and China (Reid, 19881993, I: 112). In the process it is likely that the population was increasingly thrown back on inadequate local resources, leading both to the spread of unsustainable farming practices, and to a secular decline in population as nutrition 


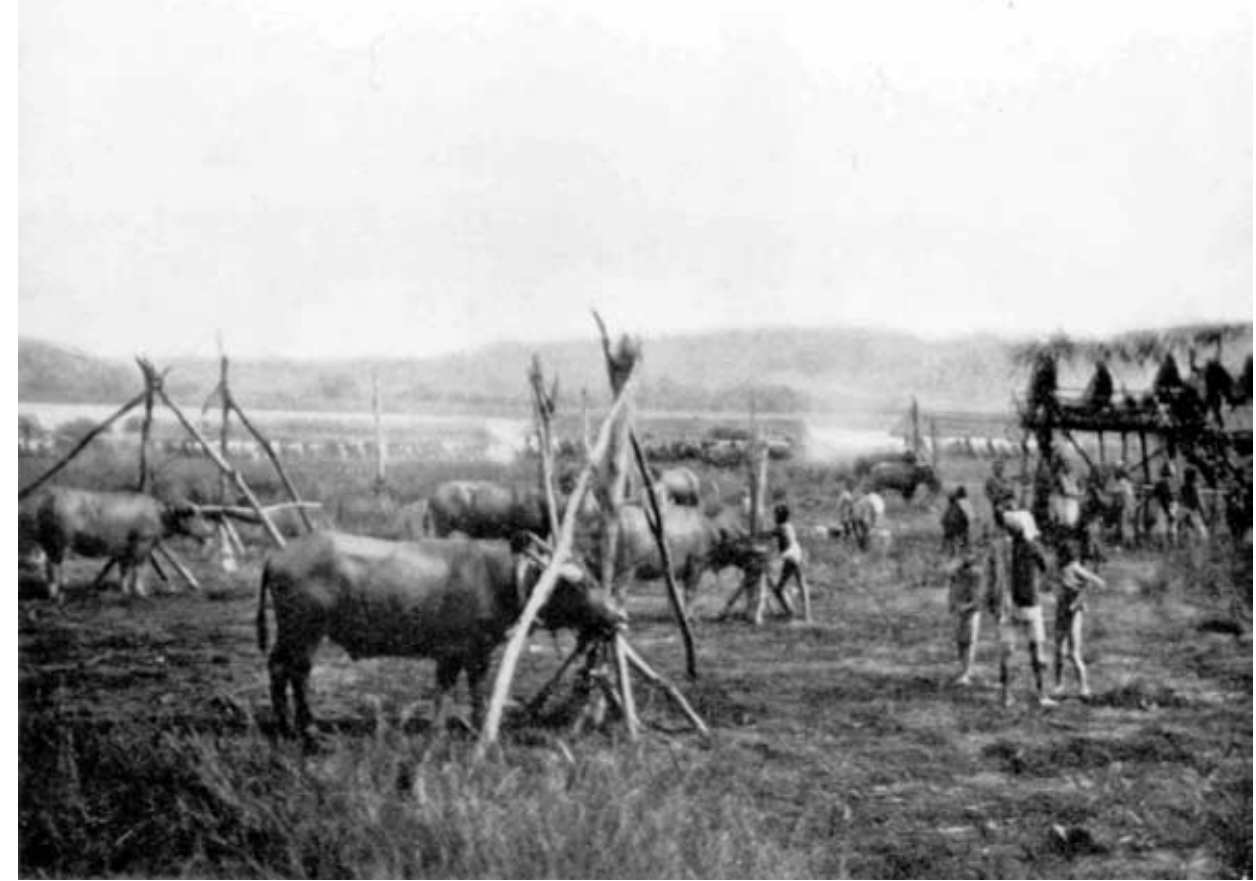

Figure 2. Water buffalo awaiting slaughter at a funeral feast, Poso area, c.1910. Source: Adriani and Kruyt (1912-1914), Deel Platen (Plaat 38). Reproduced by permission of the Royal Netherlands Institute of Southeast Asian and Caribbean Studies (KITLV)

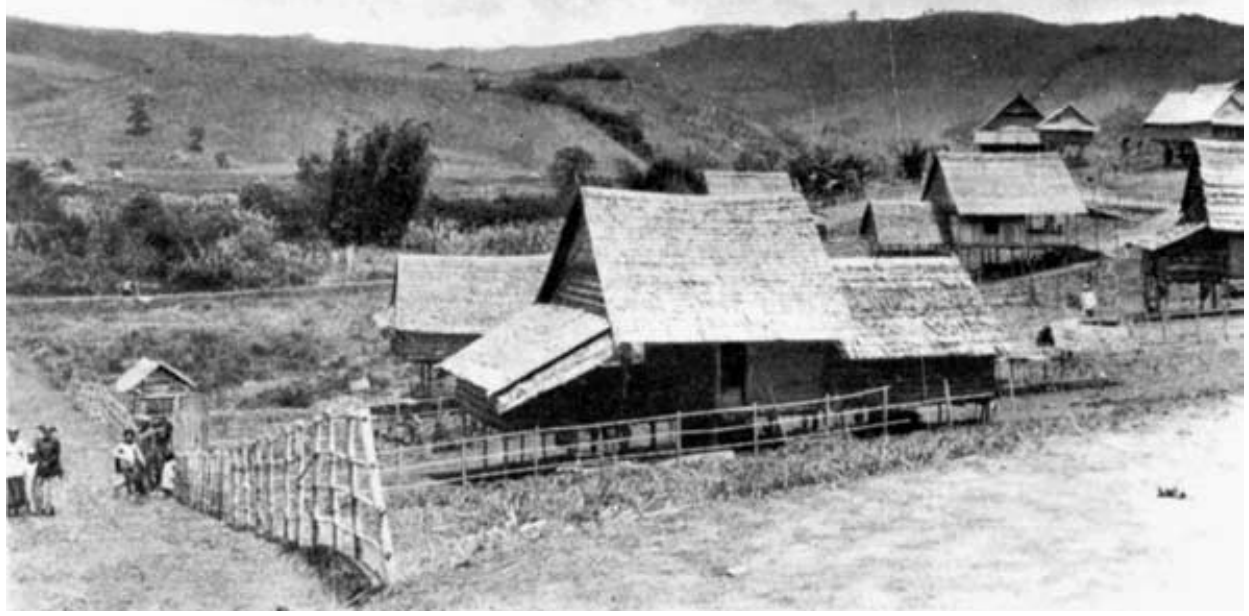

Figure 3. Tentena (on Lake Poso) with fire-climax grasslands in the background, c.1930. Source: Adriani and Kruyt (1950-1951), Deel Platen (Plaat 59). Reproduced by permission of the Royal Netherlands Institute of Southeast Asian and Caribbean Studies (KITLV) 
deteriorated, reproductive fertility declined and emigration increased. The process of repeated migration as a result of land degradation could not of course continue indefinitely, and the fact that the total population of this part of Sulawesi was still declining in the late nineteenth century suggests a continuing adjustment to its limited economic potential in the absence of the iron trade.

\section{Minahasa}

In the volcanic uplands of Minahasa at the tip of the northern peninsula, the situation was quite different. Here on the fertile plateau around Lake Tondano, the population density around 1850 already averaged at least 70 persons per square kilometre. ${ }^{20}$ At the beginning of our period the predominant farming system, as in the Poso valley, was rotational swidden cultivation, with rice and maize as principal crops. These were typically cultivated on a newly cleared swidden for either 1 or 2 years, followed by a fallow interval of 3-6 years. ${ }^{21}$ But in this area there was no periodic movement of villages, nor substantial grassland formation, nor any other sign of unsustainable land use (although the brush and young woodland which dominated the swidden fallow vegetation bore little resemblance to the natural forest which had once stood in its place). ${ }^{22}$ In Minahasa, indeed, the stability and sustainability of local swidden farming systems impressed even Dutch colonial officials, whose instinct was to condemn all such systems for their supposed wastefulness of land, labour and timber. The Minahasan farmer, conceded one administrator in 1856, 'possesses a certain degree of skill in this type of agriculture, which can be practised in a sustainable [duurzaam] way, and with good results (CV Manado 1856, in ANRI Manado 51).

Although rotational swidden farming still predominated, it was complemented by a considerable amount of irrigated rice cultivation. ${ }^{23}$ Wet rice farming has a long history in Minahasa: a Dutch document from 1689 already notes that the farmers of Tondano 'cultivate their land better' than those of neighbouring districts 'by draining or flooding it at will' (NA VOC 1461: 466r). Although colonial observers, who invariably regarded irrigation as a superior system, tended to attribute its presence to contacts with 'higher' cultures, the farmers themselves insisted that the usefulness of irrigation had been discovered accidentally in situ. ${ }^{24}$ Aside from a limited amount of technical intervention by the Dutch irrigation service towards the end of the colonial period, there is in fact little reason to think of the historical distribution and spread of irrigated farming anywhere in northern Sulawesi in terms of technological diffusion or culture contact. ${ }^{25}$ In 1857, when Dutch efforts to promote irrigation had only just begun, $21 \%$ of the total reported Minahasan rice harvest already came from wet fields; within the Tondano administrative division on the central plateau, where most of the sawah were concentrated, the proportion was 35\% (CV Manado 1857, in ANRI Manado 52).

Three factors were involved in this (by regional standards) early adoption of irrigated farming in Minahasa. The first was a favourable physical environment: on the Minahasan plateau wet fields could be constructed without much elaborate terracing, fed by small streams which were easily diverted and controlled without the aid of major earthworks, and practised in tandem with swidden cultivation as a way of diversifying the farming system. ${ }^{26}$ The second was the already highpopulation density: in the 1860s a missionary observed that if all the inhabitants of Tondano were to cultivate swiddens instead of sawah, they 'would quickly run short of ricefields, or at least be compelled to make these at a great distance from the negeri' (Wilken, 1870: 374). The third was a long-standing commercial incentive for farmers to maximise production of rice from the limited area of farmland available to them. This foodcrop was produced for sale as well as for domestic consumption, Minahasan rice having been a profitable export product since the seventeenth century if not earlier (although rice exports ceased in the second half of the nineteenth century). ${ }^{27}$ Whether or not it was routinely more labour-efficient to grow rice on wet than on dry fields, as Hunt (2000) has argued, sawah certainly permitted a greater total production from a limited land area given a willingness to make large labour investments in order to secure commercial profits.

In the 1850s, a further factor favouring irrigation was added when the colonial authorities began to take active steps to promote wet 
rice farming in Minahasa. They did this primarily because in order to facilitate administration and taxation, they were concerned that Minahasans should live permanently in large nuclear villages rather than spending much of the year in scattered swidden huts (Schouten, 1998: 59). Most Dutch officials also believed that swiddening, because it involved the constant clearance of forest, was more laborious (at least in the long run) than wet rice farming. ${ }^{28}$ On this point, however, there were also some dissenting voices, one administrator concluding that 'wet fields [...] demand a quantity of labour, both in order to create them and in order to maintain the water channels and suchlike, which in many places exceeds the capacity of the local population' (Jansen, 1861: 232). What is clear is that the initial labour investment required to construct bunded or terraced fields and water channels in less than optimal locations, as Conelly (1992: 218, 220) has confirmed in a field study from the Philippines, formed a major disincentive to this form of intensification. In the $1850 \mathrm{~s}$ and 1960s, Dutch attempts to expand the area under irrigation by administrative fiat were certainly unpopular. ${ }^{29}$

As time went by, however, local antipathy to the colonial intensification endeavour waned, and the expansion of irrigated farming once more acquired its own indigenous momentum (see Table 2). The main factor here was the onset of sustained population growth around 1860 . In the second half of the nineteenth century the population of Minahasa grew from approximately 100000 to approximately 180000 , and

Table 2. Expansion of irrigation in Minahasa, 1860-1920

\begin{tabular}{cccc}
\hline $\begin{array}{c}\text { Approximate } \\
\text { irrigated } \\
\text { area }\left(\mathrm{km}^{2}\right)\end{array}$ & $\begin{array}{c}\text { Irrigated area } \\
\text { as proportion of } \\
\text { total rice } \\
\text { production } \\
(\%)\end{array}$ & $\begin{array}{c}\text { Irrigated rice } \\
\text { production as } \\
\text { proportion of } \\
\text { total rice } \\
\text { production } \\
(\%)\end{array}$ \\
\hline $1860^{\mathrm{a}}$ & 20 & 10 & 25 \\
$1880^{\mathrm{b}}$ & 60 & 25 & 40 \\
$1920^{\mathrm{c}}$ & 135 & 35 & 60 \\
\hline
\end{tabular}

aAreas: AV Manado 1862, 1863 (ANRI Ambon 1563, Manado 52). Production: CV Manado 1859 (ANRI Ambon 1543).

b Areas: CV Manado 1879 (ANRI Manado 86). Production: Matthes, 1881.

cVan Marle (1922, II: 86-89). by 1930 it was over 300000 . This increase was accommodated partly by food imports and by an expansion of the swidden farming area at the expense of the remaining natural forest, but mostly by conversion from rotational to permanentfield farming. A report on the Tondano area from 1873 is explicit that the growing popularity of wet rice cultivation has to do with the growing scarcity of land for swidden farming (CV Tondano 1873, in ANRI Manado 19). In accordance with the view of Netting (1993: 288-294) and others that besides population pressure, 'market pull' is also a common reason for farmers to raise per hectare labour and capital inputs, the continuing commercial demand for rice may also have played a role. The level of rice production per head of the population, however, remained approximately stable after 1860 (Henley, 2005: 336), suggesting that the expansion of irrigation, in accordance with the Boserup model, was dictated less by price incentives to surplus production than by an endeavour to maintain rice harvests at existing levels under conditions of growing land scarcity. ${ }^{30}$ By the end of the colonial period the population density in some localities on the Tondano plateau had reached 400 persons per square kilometre (Tammes, 1940: 191), and the landscape in those areas was dominated by unbroken expanses of sawah (Fig. 4).

\section{Sangir}

A different type of development towards intensive, sustainable, commercial agriculture unfolded at the same period in the Sangir archipelago (Greater Sangir and its smaller neighbours Siau and Tagulandang) to the north of Sulawesi. Like Minahasa, this was an area of active volcanism and fertile alkaline soils. Population densities around 1850 were also comparable to those found on the central plateau of Minahasa: approximately 60 persons per square kilometre on the main island of Greater Sangir, 80 on Tagulandang, and perhaps as many as 100 per square kilometre on Siau, where visitors were amazed to see farmers 'working their gardens on steep slopes and among rocky outcrops where one would think that hardly a tree or a plant could gain a hold' ${ }^{31}$ Seaborne trade was probably at least as important to 


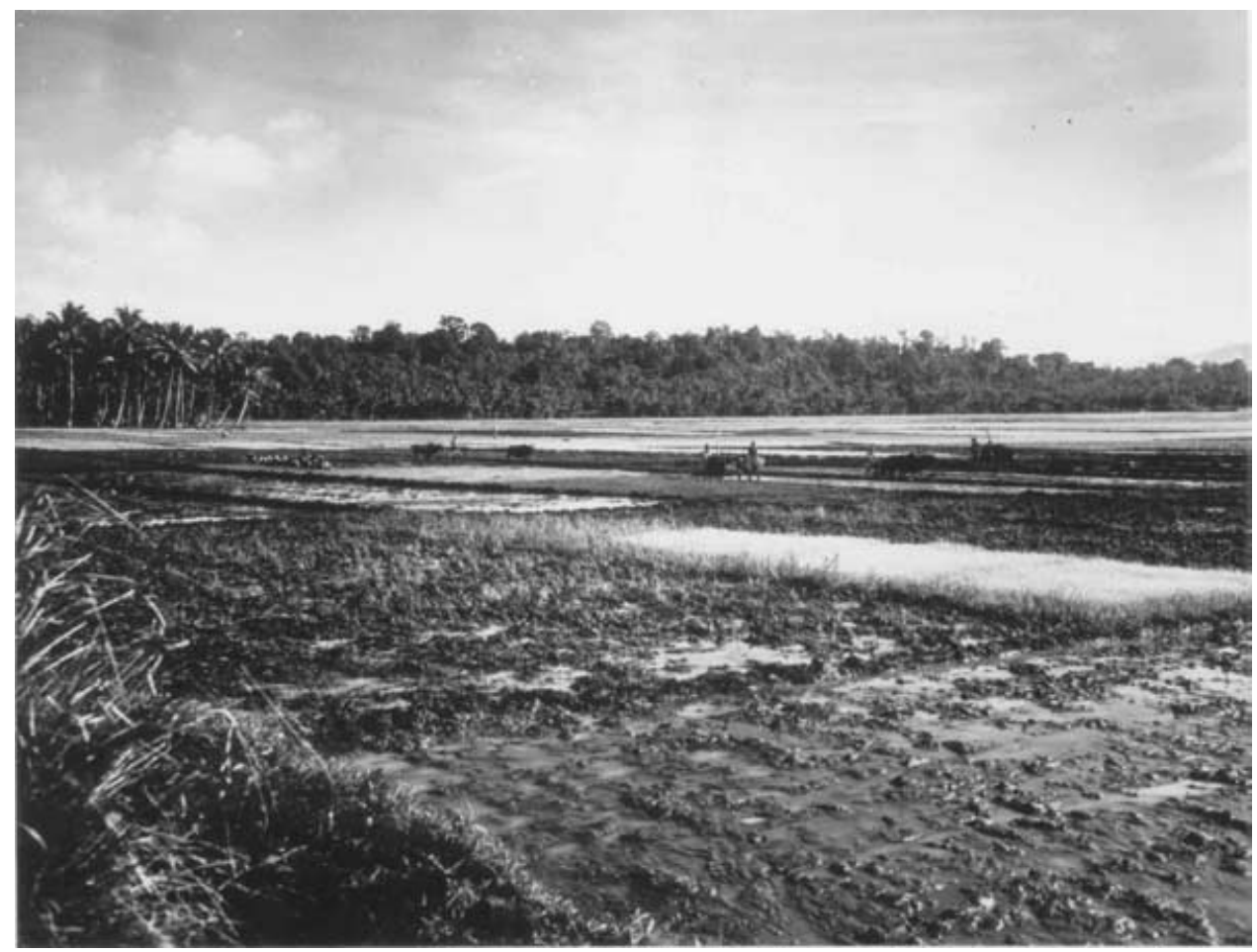

Figure 4. Irrigated ricefields near Tondano (Minahasa), 1945. Source: KITLV (Photo 6675) Reproduced by permission of the Royal Netherlands Institute of Southeast Asian and Caribbean Studies (KITLV)

the local economy as it was in Minahasa (Van de Velde van Cappellen, 1857: 50-51). Given the less terrain and long coastlines of the Sangir islands, however, the main export product here was not rice, but coconut oil for use in mainland Sulawesi and the Moluccas as cooking or lamp oil. The process of agricultural intensification, accordingly, proceeded not by means of irrigation, but rather towards a more or less integrated combination of permanent coconut gardens with a foodcrop farming system based on tubers, bananas and sago. ${ }^{32}$

As early as 1677, a Dutch visitor had already recorded that the hills of Greater Sangir, 'even the biggest and highest, are planted with coconut trees' (Van der Aa, 1867: 253254). In 1855, another declared that coconut palms were present there 'in greater numbers than perhaps anywhere else in the whole of the Indies'. ${ }^{33}$ Yet this was no coconut monoculture. Between and beneath the coconut trees, in many localities, grew a second cultivated palm: the small sagu baruk or 'Magindanao sago tree' (Arenga microcarpa), an important source of edible starch. ${ }^{34}$ Another useful understorey plant was the banana-like Manila hemp or abaca
(Musa textilis), cloth woven from the fibres of which was exported to mainland Sulawesi and the Moluccas (Buddingh, 1859-1861, II: 45). Taro, sweet potato (Fig. 5) and many varieties of edible banana were likewise sufficiently tolerant of shade (unlike rice or maize) to be planted under the light canopy of the more mature coconut gardens (Tammes, 1949: 28-29; Tergast, 1936: $131,135)$. Short-fallow rotational swidden farming, however, was also practised in areas not yet planted with coconuts (Van Delden, 1844: 18; Steller, 1866: 17-18).

In the late nineteenth and early twentieth centuries the areal intensity of agriculture in Sangir continued to increase as copra (dried coconut flesh) replaced coconut oil as the main export product, and soaring industrial demand for this commodity in Europe and North America made coconut planting ever more profitable. ${ }^{35}$ A second international export crop, nutmeg, also became significant, nutmeg trees joining sago palms in the intermediate storey of the coconut agroforests. ${ }^{36}$ The already dense population, meanwhile, grew dramatically, so that by 1930 the average density in the islands stood at 166 persons per square kilometre 


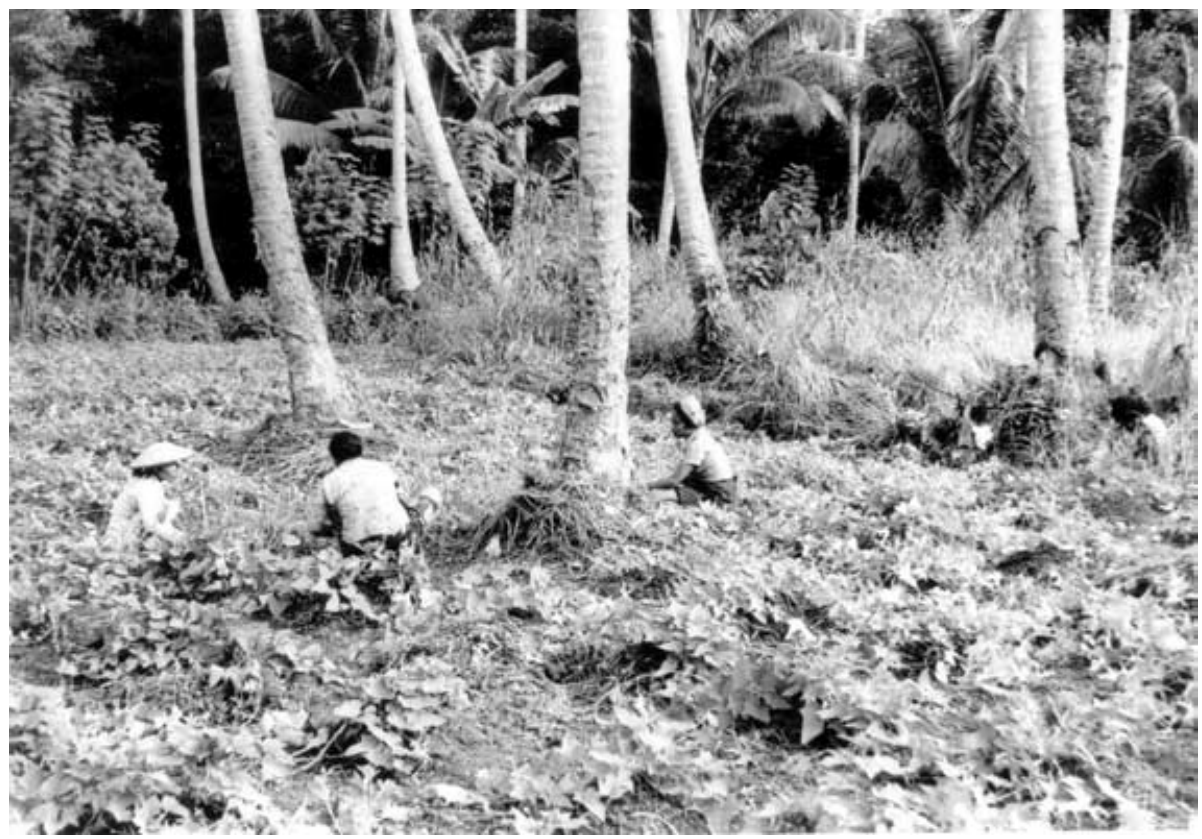

Figure 5. Women weeding a crop of sweet potato growing beneath old coconut palms in Sangir-Talaud, 1979. Source: Yayasan Mitra Budaya, Jakarta (Photo 62)

(Volkstelling 1930, V: 156). As the remaining fallow woodland made way for permanent stands of coconut trees with nutmeg or foodcrop understoreys, swidden farming was increasingly confined to land at altitudes more than $500 \mathrm{~m}$ where coconuts, as on the plateau of Minahasa, did not yield well. ${ }^{37}$ The commercial arboriculture which replaced swiddening, however, was at least as sustainable. In 1920 an official of the Dutch colonial forestry service, an organisation usually intent on preserving forests against any kind of agricultural expansion on ecological as well as economic grounds, was uncharacteristically sanguine about the likelihood of soil erosion, landslides and flooding in throroughly deforested Sangir. ${ }^{38}$

What, then, has been the impact of this deforestation in hydrological terms? Although some deleterious effects are certainly perceptible, as yet the situation gives no cause for alarm. The original forest, after all, has been almost entirely replaced by a vegetation of perennial tree crops - coconuts, nutmeg and sago which, because they are mostly planted (or have grown) in an irregular and rather dense pattern, have taken over the [water-retaining and soil protecting] function of the original forest quite effectively. (Heringa, 1921: 741)
This sustainable agroforestry system, it is worth repeating, had developed under conditions of high demographic pressure and in response to strong commercial demand for coconut oil, copra and nutmeg. In order to support the growing population, foodcrop agriculture was integrated with the coconut gardens, and increasingly also supplemented by rice imports paid for using the profits from cash crop exports (Van Dinter, 1899: 339; Tergast, 1936: 131). The contrast with Poso in Central Sulawesi, where a sparse population practising subsistence swidden farming and non-commercial animal husbandry converted huge areas of forest to grassland or savanna, and in the process apparently threatened the viability of its own economy, could hardly be more dramatic. ${ }^{39}$

The soil resources of Sangir, as already noted, were intrinsically more amenable to sustained agricultural use than were those of Central Sulawesi, but of course even at the beginning of our period, they also had to support a much denser population. The impression of a Malthusian relationship between population and resources which arises from the geographical correlation between population density and soil fertility is strengthened by the fact that, historically speaking, episodes of demographic growth were usually associated with increases 
in agricultural production stimulated by new commercial opportunities. Rapid growth of the population of Sangir (from perhaps 55000 to 95000 ) between 1850 and 1900, for example, took place largely outside the influence of the Dutch authorities in Minahasa and was not accompanied by any dramatic cultural transformation or change in health conditions, but did coincide with the great acceleration of commerce and coconut planting brought about by the copra export boom. Given the precision of this correlation and the absence of convincing alternative explanations, as the colonial biologist Tammes (1940: 190) pointed out in a pioneering article on the historical demography of the region, the main factor behind population growth in Sangir during the late nineteenth century can only have been the expansion of economic opportunities [bestaansmogelijkheden] - specifically, the cultivation of commercial crops'. $^{40}$

\section{Conclusion}

Wet rice cultivation, clearly, was not the only way of supporting a dense and growing agrarian population on a sustainable basis under equatorial conditions. Another, perfected in Sangir, was to cultivate commercial tree crops in an integrated agroforestry combination with nongrain food plants, supplemented by rice imports. What Minahasa and Sangir nevertheless did have in common in the period under consideration here, other than dense populations, was favourable environmental (particularly soil) conditions, and economies which were relatively commercialised - that is, oriented towards exchange rather than self-sufficiency. Although their volcanic soils were intrinsically more suitable for sustained agricultural use than were the shallow, leached types found elsewhere in the region (and in many other parts of Indonesia), their access to foreign markets created demand for the tree crops on which the agroforestry of Sangir was based, and stimulated the development of the domestic markets by means of which Minahasan sawah farmers sold much of their harvest. ${ }^{41}$ Meanwhile their high population densities, themselves essentially consequences of productive environments and economies, were also conducive to sustainable intensification in that they necessitated area-efficient production methods and en- sured an abundant per hectare supply of labour for investment in 'landesque capital' such as bunded fields and planted trees. ${ }^{42}$

Partly because population densities tended to adjust themselves in a broadly Malthusian way to local economic conditions, the agricultural practices of the Indonesian past were typically sustainable in the sense that yields did not decline over time - although it should be added that bush-fallow swiddening, probably the most widespread foodcrop farming system, was still highly destructive of natural forest. Episodes of population growth, powered by increases in commerce, were accompanied by food imports and/or by capital and labour investments which made possible higher yields per hectare of farmland. But although fertile, populous, commercialised areas like Sangir and Minahasa were able to support rapidly growing populations on a sustainable basis, sparsely populated areas of low agricultural potential were sometimes subject to environmental degradation, especially during periods of disengagement from commerce when populations which had previously depended partly on trade were thrown back on purely local resources. This was the case during the nineteenth century in the Poso area of Central Sulawesi, once part of a flourishing iron export economy but by that stage a commercial backwater where itinerant shifting cultivation on very poor land, combined with the use of fire to create pasture for (non-commercial) livestock grazing, had brought about land degradation and the progressive conversion of forest to fire-climax grassland and savanna. ${ }^{43}$

\section{Abbreviations}
ANRI Arsip Nasional Republik Indonesia
AV Algemeen/Administratief Verslag (Gen- eral/Administrative Report)
CV Cultuur Verslag (Cultivation Report)
KITLV Koninklijk Instituut voor Taal-, Land- en Volkenkunde (Leiden)
$\mathrm{MvO}$ Memorie van Overgave (NA collection, divided into two series: KIT and MMK)
NA Nationaal Archief (The Hague)
VOC Verenigde Oostindische Compagnie (Dutch East India Company)

\section{Notes}

1 For instance: Angelsen, 1995: 1724-1725; Booth, 1985: 143; Conelly, 1992: 206-207; Donner, 1987: 
66-67, 70, 76-77; Elson, 1997: 14, 106-110; Hafner, 2000: 139; Heersink, 1998: 114; Henkemans et al., 2000: 58, 62; Hill, 1998: 3, 14; Hirschman, 1994: 383; Kartomo Wirosuhardjo, 1993: 160; Knapen, 2001: 399-402; Nibbering, 1997: 155; Palte, 1989; Rigg, 1986: 34-35, 43; 1991: 41-42; Seavoy, 1980; Uhlig, 1984: 16, 20, 23; 1995: 158-164.

2 Also: Bottema, 1995: 155; Eder, 1991: 246; Rigg, 1991: 42. Compare: Goldman and Smith, 1995: 258-259; Netting, 1993: 288-294.

3 The term 'Malthusian' as used here refers to the view that population, whether by the 'preventive check' of fertility control or by the 'positive check' of mortality, 'must always be kept down to the level of the [existing] means of subsistence' (Malthus, 1976: 15). It does not imply a dramatic resource crisis caused by excessive population growth. When Malthus made his famous comparison between the geometric rate of population increase which reproductive biology makes possible and the (at most) arithmetical rate at which he supposed the means of economic subsistence could be expanded (1976: 21-23), his intention was not to predict that population numbers would one day massively outstrip the available resources, but precisely to show that in reality this was never likely to happen.

4 Allen, 2001: 250-251; Booth, 1985: 142; 1988: 67; 1998: 248.

5 Dobby, 1950: 389; Knaap, 1987: 121-122; 1995: 239; Tammes, 1940: 196-197; Wander, 1965: 212.

6 Classically described at the end of the colonial period by Mohr (1938a: 245, 248-251; 1938b), this relationship has been commented on in passing by many subsequent authors: Boomgaard, 1997: 3-4; Dobby, 1950: 387; Donner, 1987: 9, 174; Fisher, 1967: 157; Hardjono, 1971: 127; Hugo, 2000: 96; Levang, 1997:104; Lindert, 2000: 199; Löffler, 1982: 131; Repetto, 1986: 16; Rigg, 1991: 83; Robequain, 1946: 107-109; Zimmerman, 1992: 128.

7 Even if we accept that the total population of Java (with Madura) in 1800 was only 7.5 million (Boomgaard and Gooszen, 1991: 82), its average population density was already over 55 persons per square kilometre. In 1930, by comparison, the equivalent figures for Sumatra and Borneo were still only 17 and four persons, respectively (Volkstelling 1930, IV: 157; V: 155).

8 Reid (1988-1993, I: 20) argues that at least in precolonial times, its distribution in South-East Asia 'was determined primarily by the physical conditions of each area and only secondarily by population pressure'. Compare also: Elson, 1997: 8, 14; Knapen, 2001: 199-203; Stone, 2001: 174. Further support for a non-Boserupian view regarding irrigation comes from the Pacific (Leach, 1999), where yields of taro grown in pond-fields 'are on the order of eight times that of a swidden garden, yet require approximately the same labour inputs once the landesque capital infrastructure is in place' (Kirch, 1994: 19).

9 Keesing, 1962: 320; Kirch, 1994: 308. Exponents of the alternative, diffusionist interpretation of terracing and irrigation in the South-East Asian context have included Spencer and Hale (1961: 30-38) and Mabbett (1977: 10-12). Brookfield himself once judged that the 'skilled terracing' found on some Melanesian islands 'more likely [...] represents a cultural diffusion than an independent innovation', although he also noted the 'wide gap between Island Melanesia and the putative area of origin of irrigated terracing in southeast Asia' (Brookfield and Hart, 1971: 81-82).

10 Van Beukering, 1947; Dobby, 1950: 348-349; Freeman, 1955: 117-118; 126-141; Geertz, 1963: 25-28; Gonggrijp, 1938: 398-401; Gourou, 1940: 347-348; 1947: 47-49; Hagreis, 1931: 606-610, 620; Ormeling, 1955: 184-186, 207-211; Pelzer, 1945: 18-21, 29-30.

11 The classic early studies of such 'integral' swidden farming systems are those by Conklin (1957) and Isikowitz (1951). Some literature from this period, however, does already acknowledge that one potential way to stabilise less benign forms of shifting cultivation would be to have farmers replace annual food crops with commercial tree crops, and live on imported food purchased using the resulting money income (Gourou, 1940: 348; Pelzer, 1945: 34; 1963: 122-124).

12 Barlow, 1991; Belsky, 1993; Cairns and Garrity, 1999; Cramb, 1998; Dove, 1993; Filius, 1997; De Foresta and Michon, 1997; Henkemans et al., 2000; Iskandar and Ellen, 2000; Kartasubrata et al., 1990; Kaya et al., 2002; Kummer et al., 1994; Michon and De Foresta, 1995; Nibbering, 1999; Salafsky, 1995; Smiet, 1990; Stoney and Bratamihardja, 1990. Some authors use the term 'agroforestry' to include the enrichment of swiddenfallow vegetation with non-commercial tree crops, or even the use of woodland fallow as such, so that in effect it becomes a synonym for rotational swidden cultivation (Colfer and Dudley, 1993: 77; Colfer et al., 1997: 156, 158; Sinclair, 1999: 175). But trees in Indonesia (with the exception of sago-producing species in some restricted areas) have never been sources of staple foodstuffs, and the high light requirements of staple foodcrops generally mean that these cannot be grown under a forest canopy (Donner, 1987: 167).

13 Hardjono, 1991: 145-149; Hefner, 1990: 104-112; Lewis, 1992: 174-186, 246-249; Rigg, 1997: 256. Nibbering (1991: 113, 1997: 175-176), however, has documented the terracing of unirrigated slopes in upland Java and elsewhere as a spontaneous and successful reaction by peasant farmers to incipient problems of soil erosion and fertility depletion.

14 Blaikie and Brookfield, 1987; Platteau, 2000; Tiffen, 1995, 1996; Tiffen and Mortimore, 1994; Tiffen et al., 1994.

15 Boserup, 1965: 78-87; Netting, 1993: 157-188; Platteau, 2000: 75-92. This latter, institutional aspect of agricultural intensification will not be considered below in relation to Sulawesi, but I have discussed it briefly elsewhere (Henley, 2002: 193).

16 A detailed description of the geography, demography and economic history of northern Sulawesi before 1930 appears in my book Fertility, food and fever; Population, economy and environment in North and Central Sulawesi, 1600-1930 (Henley, 2005).

17 Adriani, 1919: 9-10; Adriani and Kruyt, 1950-1951, I: 167; Gallas, 1900: 813; Van Hoëvell, 1893: 30; Kruyt, 1895-1897, III: 131; 1899: 608-609. In principle the infertility of the soil could have been compensated for 
by allowing longer fallow cycles, but in practice the length of the swidden rotation was limited for other reasons. One was that, as in many other parts of Indonesia (Seavoy, 1973: 219), farmers in northern Sulawesi usually preferred to recultivate secondary woodland while the girth of the trees was such that they could still be felled using a machete rather than an axe (Adriani and Kruyt, 1912-1914, II: 239; Graafland, 1864: 20). Another was that longer cycles would have meant an increase in the distance between the outlying swidden houses and the nuclear village, ready access to which was essential under precolonial conditions for defensive purposes (Crawfurd, 1820, I: 221; Gullick, 1958: 29).

18 Because of the limited amount of fertile ash which grass yielded after burning, and the heavy labour involved in extracting grass root mats from the soil or weeding their fast-growing shoots, grasslands were difficult to reincorporate into the swidden farming cycle (Adriani and Kruyt, 1912-1914, II: 239). Once grass or savanna vegetation began to dominate the landscape, moreover, fires became more difficult to keep under control (Adriani and Kruyt, 1900: 206-207). For these reasons extensive livestock grazing, although in the short term, a rational use for degraded land, ultimately tended to exacerbate sustainability problems when practised in association with shifting cultivation (Gourou, 1940: 348, 368-370; Terra, 1958: 170-171).

19 Banggai, the polity which originally controlled most of the iron trade, was mentioned as early as the fourteenth century in both Chinese and Javanese sources (Ptak, 1992: 29, 31; Robson, 1995: 34).

20 In 1920, Van Marle (1922, I: 48) calculated the average density on the plateau at 169 inhabitants per $\mathrm{km}^{2}$. The Minahasan population as a whole was roughly 2.3 times larger in 1920 than in 1850 (Bleeker, 1856: 31; Van Marle, 1922, I: 47), between which dates its distribution also changed significantly in favour of the coastal lowlands (Schouten, 1998: 181; Tammes, 1940: 192).

21 Van Doren, 1857-1860, II: 362; Francis, 1856-1860, III: 350; Grudelbach, 1849: 406; Olivier, 1834-1837, II: 35; Reinwardt, 1858: 585. References to longer fallow periods from Minahasa at the same period refer to less fertile and less densely populated areas outside the central plateau (De Clercq, 1870: 526-527; Teysman, 1861: 344).

22 The typical mature fallow vegetation consisted of a handful of pioneer tree species 5 or $6 \mathrm{~m}$ tall and a few centimetres in stem diameter (Koorders, 1898: 26). Similarly short fallow intervals were also the norm in many other parts of Indonesia (Colfer and Dudley, 1993: 60; Ellen, 1978: 117; Seavoy, 1973: 219; Van Steenis, 1937: 638). This is clearly at odds with the persistent myth that under conditions of traditional 'shifting' cultivation, 'the interaction of humans with the Southeast Asian rainforest was primarily one of interdependence' since 'population pressures were low enough for routine regeneration' (Reid, 1995: 93).

23 Edeling, 1919: 58; Francis, 1856-1860, III: 344-348; Jansen, 1861: 232-235; Wilken, 1870: 373-374.
24 Wilken, 1870: 373 . Some of the local rice varieties, it is worth adding in this context, could be grown on both dry and flooded fields (De Clercq, 1871: 4).

25 Knowledge of irrigation techniques, significantly, was always a good deal more widespread within the region than their actual practice: Adriani (1915: 470) noted that although farmers in the Poso valley had never made irrigated fields themselves, they nevertheless 'knew perfectly well what was involved in wet rice cultivation' as a result of long contact with their sawah-farming neighbours further west.

26 Compare: Padoch, 1985: 285; Reid, 1988-1993, I: 20; 1995: 78; Scholz, 1988: 10-12; Stargardt, 1992: 61.

27 Destined mostly for the Moluccas, this rice was exported partly in the context of statutory (but still usually remunerative) purchases by the Dutch authorities, and partly by free traders (Godée Molsbergen, 1928: 30, 122).

28 CV Manado 1856 (ANRI Manado 51), 1859 (ANRI Ambon 1543); Edeling, 1919: 46, 58; Wilken, 1870: 374; Wilken and Schwarz, 1867: 364.

29 AV Manado 1833 (ANRI Manado 48); CV Manado 1856, 1861, 1862, 1864, 1866 (ANRI Manado 39, 51, 52, 95; Ambon, 1563); Francis, 1856-1860, III: 355; Graafland, 1898, I: 148; Jansen, 1861: 232; Wilken, 1870: 374.

30 An analogous case of demographically induced economic innovation is described in an anthropological study of 'subsistence trade' in the vicinity of Lake Tondano in the 1980s. The extent to which farming households were also involved in part-time trading activities, according to this study, was largely a function of land ownership: 'the less land that is available to a household, the more important it is to trade', since trading 'has to compensate for the inadequacy of agriculture to provide for household reproduction' (Mai and Buchholt, 1987: 108, 113).

31 Van Delden, 1844: 362. Contemporary population figures for Sangir in the mid-nineteenth century are severe underestimates; these approximate figures are based on reconstructions from a range of contextual data.

32 All the land under coconut trees may initially have been cleared for swidden farming purposes: 'the coconut plantations', as a Dutch administrator put it, 'come into being by means of foodcrop agriculture' (Van Rhijn, 1941: 42). But the longevity of the coconut palm meant that it could not practically be incorporated into a continued swidden rotation (Tammes, 1949: 17, 39).

33 Van de Velde van Cappellen, 1857: 45. Also: Hickson, 1889: 174; Van Delden, 1844: 362; Steller, 1866: 17. The export of coconut oil from Sangir dates back at least to the middle of the seventeenth century (Hustaart, 1656).

34 Steller, 1866: 17; Tammes, 1936: 43, 48; Tergast, 1936: 138.

35 The export of copra from Siau dates from 1862 (Van Dinter, 1899: 334), and in 1880 a German trading firm established an agency on Greater Sangir in order to buy up this product directly (Matthes, 1881). By the beginning of the twentieth century, Sangir as a whole 
was apparently exporting at least 5000 tonnes of copra, or approximately $50 \mathrm{~kg}$ for every inhabitant, each year (Encyclopaedisch Bureau, 1912: 49).

36 Van Dinter, 1899: 335-337; Janse, 1898: 19-20; Tergast, 1936: 132, 135. Manila hemp cultivation, however, all but disappeared in the same period as cheap industrial textile imports rendered abaca weaving redundant.

37 Tergast, 1936: 135. All the major Sangir islands had been 'completely cleared for cultivation' by 1920 (Heringa, 1921: 733).

38 The supply of wood was now insufficient for local construction needs, so that despite deliberate planting of fast-growing timber species, wood had to be imported from elsewhere (Heringa, 1921: 734, 741).

39 Striking early comments by European visitors on the extent of grasslands in the Poso valley and neighbouring areas include: Grubauer, 1913: 443; Kaudern, 1925: 24; Kruyt, 1895-1897, III: 153; 1899: 604; Steup, 1931: 1132-1133.

40 Elsewhere I provide further examples of this articulation between economic and demographic change, and attempt to identify the complex and often obscure causal processes involved (Henley, 2002: 178190; 2005: 435-467). Reid (2001: 51), likewise, has argued that throughout South-East Asian history, periods of economic expansion have 'coincided with, and probably in complex ways caused', episodes of population growth. An example of the converse process - commercial contraction leading to demographic decline - was sketched above in relation to Poso.

41 This is not to deny that under other circumstances, commercial land use could itself take destructive forms even before the modern era of mechanised logging and the wholesale clearance of rainforests to make way for oil palm and other tree crop plantations. In parts of Kalimantan (Knapen, 2001: 266, 303-304) and Sumatra (Reid, 1995: 101-103), the fire-climax grasslands maintained for grazing and hunting purposes in precolonial times were located on land originally degraded by the cultivation of pepper for international markets. It is also possible that the use of timber in iron smelting contributed to early deforestation in eastern Central Sulawesi (Kruyt, 1901: 152-153).

42 It no doubt also made for lower transport and 'interaction costs' in trade, thereby further stimulating commercialisation and economic growth (Platteau, 2000: 50; Tiffen et al., 1994: 261-273).

43 After the Dutch conquest of Central Sulawesi at the beginning of the twentieth century, the situation was successfully stabilised by means other than the usual combination of commercial development and population growth. Here, however, the transition to intensive, sustainable agriculture was achieved only by means of 'a massive resettlement plan, forcing all the highlanders to abandon their hilltop hamlets and construct larger villages in the few alluvial plains suitable for wet-rice agriculture', in the course of which 'whole territories in the interior were depopulated' (Schrauwers, 2000: 71-72).

\section{References}

Adriani, N. (1915) Maatschappelijke, speciaal economische verandering der bevolking van Midden-Celebes, sedert de invoering van het Nederlandsch gezag aldaar, Tijdschrift van het Koninklijk Nederlandsch Aardrijkskundig Genootschap 32: 457-475.

Adriani, N. (1919) Posso (Midden-Celebes). Den Haag: Zendingsstudie-Raad.

Adriani, N. and A.C. Kruyt (1900) Van Posso naar Mori, Mededeelingen van wege het Nederlandsch Zendelinggenootschap 44: 135-214.

Adriani, N. and A.C. Kruyt (1912-1914) De Bare'esprekende Toradja's van Midden-Celebes, 3 vols. Batavia: Landsdrukkerij.

Adriani, N. and A.C. Kruyt (1950-1951) De Bare'e sprekende Toradjas van Midden-Celebes (de Oost-Toradjas), 3 vols. Amsterdam: Noord-Hollandsche.

Allen, B.J. (2001) Boserup and Brookfield and the association between population density and agricultural intensity in Papua New Guinea, Asia Pacific Viewpoint 42: 237254.

Angelsen, A. (1995) Shifting cultivation and 'deforestation': A study from Indonesia, World Development 23: 17131729.

Barlow, C. (1991) Developments in plantation agriculture and smallholder cash-crop production, in J. Hardjono (ed.), Indonesia: Resources, ecology, and environment. Singapore: Oxford University Press.

Belsky, J.M. (1993) Household food security, farm trees, and agroforestry: A comparative study in Indonesia and the Philippines, Human Organization 52: 130-141.

Blaikie, P. and H. Brookfield (eds.) (1987) Land degradation and society. London: Methuen.

Bleeker, P. (1856) Reis door de Minahassa en den Molukschen archipel, gedaan in de maanden September en October 1855, 2 vols. Batavia: Lange.

Boomgaard, P. (1997) Introducing environmental histories of Indonesia, in P. Boomgaard, F. Colombijn and D. Henley (eds.), Paper landscapes: Explorations in the environmental history of Indonesia. Leiden: KITLV Press.

Boomgaard, P. and A.J. Gooszen (1991) Population trends 1795-1942. Amsterdam: Royal Tropical Institute. (Changing Economy in Indonesia 11.)

Booth, A. (1985) Accommodating a growing population in Javanese agriculture, Bulletin of Indonesian Economic Studies 21: 115-145.

Booth, A. (1988) Agricultural development in Indonesia. Sydney: Allen and Unwin.

Booth, A. (1991) Regional aspects of Indonesian agricultural growth, in J. Hardjono (ed.), Indonesia: Resources, ecology, and environment. Singapore: Oxford University Press.

Booth, A. (1998) The Indonesian economy in the nineteenth and twentieth centuries: A history of missed opportunities. Houndmills, Basingstoke: MacMillan Press.

Boserup, E. (1965) The conditions of agricultural growth: The economics of agrarian change under population pressure. London: George Allen and Unwin. 
Bottema, J.W.T. (1995) Market formation and agriculture in Indonesia from the mid 19th century to 1990. PhD thesis, Katholieke Universiteit Nijmegen.

Brookfield, H. (1972) Intensification and disintensification in Pacific agriculture: A theoretical approach, Pacific Viewpoint 13(1): 30-48.

Brookfield, H. (1984) Intensification revisited, Pacific Viewpoint 25(1): 15-44.

Brookfield, H. (1993) Conclusions and recommendations, in H. Brookfield and Y. Byron (eds.), South-East Asia's environmental future: The search for sustainability. Tokyo: United Nations University Press.

Brookfield, H. (2001a) Exploring agrodiversity. New York: Columbia University Press.

Brookfield, H. (2001b) Intensification, and alternative approaches to agricultural change, Asia Pacific Viewpoint 42: 181-192.

Brookfield, H. and D. Hart (1971) Melanesia: A geographical interpretation of an island world. London: Methuen.

Buddingh, S.A. (1859-1861) Neêrlands-Oost-Indie: Reizen over Java, Madura, Makasser, Saleijer, Bima, Menado, Sangier eilanden, Talau-eilanden, Ternate [...], 3 vols. Rotterdam: M. Wijt.

Cairns, M. and D.P. Garrity (1999) Improving shifting cultivation in Southeast Asia by building on indigenous fallow management strategies, Agroforestry Systems 47: 37-48.

Colfer, C.J.P. and R. Dudley (1993) Shifting cultivators of Indonesia: Marauders or managers of the forest? Rice production and forest use among the Uma' Jalan of East Kalimantan. Rome: Food and Agriculture Organization of the United Nations.

Colfer, C.J.P., N. Peluso and C.S. Chung (1997) Beyond slash and burn: Building on indigenous management of Borneo's tropical rain forests. New York: The New York Botanical Garden.

Conelly, W.T. (1992) Agricultural intensification in a Philippine frontier community: Impact on labor efficiency and farm diversity, Human Ecology 20: 203223.

Conklin, H.C. (1957) Hanunóo agriculture: A report on an integral system of shifting cultivation in the Philippines. Rome: Food and Agriculture Organization of the United Nations.

Cramb, R. (1998) Environment and development in the Philippine uplands: The problem of agricultural land degradation, Asian Studies Review 22: 289-308.

Crawfurd, J. (1820) History of the Indian Archipelago. Containing an account of the manners, arts, languages, religions, institutions, and commerce of its inhabitants, 3 vols. Edinburgh: Archibald Constable.

Dames, T.W.G. (1955) The soils of East Central Java. Bogor: General Agricultural Research Station.

De Clercq, F.S.A. (1870) De overzijde der Ranojapo, Tijdschrift voor Indische Taal-, Land- en Volkenkunde 19: 521-539.

De Clercq, F.S.A. (1871) De voornaamste padisoorten geteeld op de droge velden in de Minahasa, Tijdschrift voor Nederlandsch Indië 5: 1-7.

De Foresta, H. and G. Michon (1997) The agroforest alternative to Imperata grasslands: When smallholder agriculture and forestry reach sustainability, in D.P. Garrity (ed.), Agroforestry innovations for Imperata grassland rehabilitation. Dordrecht: Kluwer Academic.

Dobby, E.H.G. (1950) Southeast Asia. London: University of London Press.

Donner, W. (1987) Land use and environment in Indonesia. Honolulu: University of Hawaii Press.

Dove, M.R. (1985) The agroecological mythology of the Javanese and the political economy of Indonesia, Indonesia 39: 1-36.

Dove, M.R. (1993) Smallholder rubber and swidden agriculture in Borneo: A sustainable adaptation to the ecology and economy of the tropical forest, Economic Botany 47: 136-47.

Edeling, A.C.J. (1919) Memorie omtrent de Minahasa, Adatrechtbundel 16: 5-95.

Eder, J.F. (1991) Agricultural intensification and labor productivity in a Philippine vegetable gardening community: A longitudinal study, Human Organization 50: 245-255.

Ellen, R.F. (1978) Nuaulu settlement and ecology: An approach to the environmental relations of an eastern Indonesian community. The Hague: Martinus Nijhoff.

Elson, R.E. (1997) The end of the peasantry in Southeast Asia: A social and economic history of peasant livelihood, 1800-1990s. Houndmills, Basingstoke: MacMillan Press.

Encyclopaedisch Bureau (1912) De zelfbesturende landschappen Tahoelandang, Siaoe, Taboekan, KandharTaroena en Manganitoe op de Sangi- en Talaudeilanden, Mededeelingen van het Bureau voor de Bestuurszaken der Buitenbezittingen 2: 5-82.

Filius, A.M. (1997) Factors changing farmers' willingness to grow trees in Gunung Kidul (Java, Indonesia), Netherlands Journal of Agricultural Science 45: 329345.

Fisher, C.A. (1967) Economic myth and geographical reality in Indonesia, Modern Asian Studies 1: 155-189.

Francis, E. (1856-1960) Herinneringen uit den levensloop van een' Indisch' ambtenaar van 1815 tot 1851, 3 vols. Batavia: H.M. van Dorp.

Freeman, J.D. (1955) Iban agriculture: A report on the shifting cultivation of hill rice by the Iban of Sarawak. London: Her Majesty's Stationery Office.

Gallas, P.A. (1900) Bijdrage tot de kennis van het landschap Poso, Tijdschrift van het Koninklijk Nederlandsch Aardrijkskundig Genootschap 17: 801-814.

Geertz, C. (1963) Agricultural involution: The process of ecological change in Indonesia. Berkeley: University of California Press.

Godée Molsbergen, E.C. (1928) Geschiedenis van de Minahassa tot 1829. Weltevreden: Landsdrukkerij.

Goldman, A. and J. Smith (1995) Agricultural transformations in India and northern Nigeria: Exploring the nature of Green Revolutions, World Development 23: 243-263.

Gonggrijp, J.W. (1938) Soil management and density of population in the Netherlands Indies, in Comptes Rendus du Congrès International de Géographie Amsterdam 1938, Vol. 2, Géographie Coloniale. Leiden: E.J. Brill.

Gourou, P. (1940) L'utilisation du sol en Indochine française. Paris: Centre d'études de Politique étrangère. 
Gourou, P. (1947) Les pays tropicaux: Principes d'une géographie humaine et économique. Paris: Presses universitaires de France.

Graafland, N. (1864) Fragment eener onuitgegevene beschrijving van de Minahassa, Mededeelingen vanwege het Nederlandsch Zendelinggenootschap 8: 1-23.

Graafland, N. (1867-1969) De Minahassa. Haar verleden en haar tegenwoordige toestand, 2 vols. Rotterdam: M. Wijt.

Grubauer, A. (1913) Unter Kopfjägern in Central-Celebes: Ethnologische Streifzüge in Südost- und CentralCelebes. Leipzig: R. Voigtländers Verlag.

Grudelbach, J. (1849) Het meer van Tondano en omstreken, Indisch Archief 1(1): 399-407.

Gullick, J.M. (1958) Indigenous political systems of western Malaya. London: The Athlone Press.

Hafner, J.A. (2000) Perspectives on agriculture and rural development, in T.R. Leinbach and R. Ulack (eds.), Southeast Asia: Diversity and development. Upper Saddle River, NJ: Prentice Hall.

Hagreis, B.J. (1931) Ladangbouw, Tectona 24: 598-621.

Hanks, L.M. (1972) Rice and man: Agricultural ecology in Southeast Asia. Chicago: Aldine Atherton.

Hardjono, J. (1971) Indonesia, land and people. Jakarta: Gunung Agung.

Hardjono, J. (1991) Environment or employment: Vegetable cultivation in West Java, in J. Hardjono (ed.), Indonesia: Resources, ecology, and environment. Singapore: Oxford University Press.

Heersink, C. (1998) Environmental adaptations in southern Sulawesi, in V.T. King (ed.), Environmental changes in South-East Asia. Richmond, Surrey: Curzon.

Hefner, R.W. (1990) The political economy of mountan Java: An interpretive history. Berkeley: University of California Press.

Henkemans, A.B., G.A. Persoon and K.F. Wiersum (2000) Landscape transformations of pioneer shifting cultivators at the forest fringe, in K.F. Wiersum (ed.), Tropical forest resource dynamics and conservation: From local to global issues. Wageningen: Department of Environmental Sciences, Wageningen University.

Henley, D. (2002) Population, economy and environment in island Southeast Asia: An historical view with special reference to northern Sulawesi, Singapore Journal of Tropical Geography 23: 167-206.

Henley, D. (2005) Fertility, food and fever: Population, economy and environment in North and Central Sulawesi, 1600-1930. Leiden: KITLV Press.

Heringa, P.K. (1921) Rapport over de begroeiing van de Sangi- en Talaud-eilanden, Tectona 14: 733-746.

Hickson, S.J. (1889) A naturalist in North Celebes: A narrative of travels in Minahassa, the Sangir and Talaut islands, with notices of the fauna, flora and ethnology of the districts visited. London: John Murray.

Hill, R.D. (1998) Stasis and change in forty years of Southeast Asian agriculture, Singapore Journal of Tropical Geography 19: 1-25.

Hirschman, C. (1994) Population and society in twentiethcentury Southeast Asia, Journal of Southeast Asian Studies 25: 381-416.

Hugo, G. (2000) Demographic and social patterns, in T.R. Leinbach and R. Ulack (eds.), Southeast Asia: Diversity and development. Upper Saddle River, NJ: Prentice Hall.

Hunt, R.C. (2000) Labour productivity and agricultural development: Boserup revisited, Human Ecology 28: 251-277.

Hustaart, J. (1656) Schriftelijk vertoog van den tegenwoordigen staat der Vereenigde Nederlandsche Oostindische Comp: e in 't gouvernement der Moluxe eijlanden. (KITLV H454e)

Isikowitz, K.G. (1951) Lamet: Hill peasants in French Indochina. Göteborg: Etnografiska Museet.

Iskandar, J. and R.F. Ellen (2000) The contribution of Paraserianthes (Albizia) falcataria to sustainable swidden management practices among the Baduy of West Java, $\mathrm{Hu}$ man Ecology 28: 1-17.

Janse, J.M. (1898) De nootmukaat-cultuur in de Minahassa en op de Banda-eilanden. Batavia: G. Kolff.

Jansen, A.J.F. (1861) De landbouw in de Minahasa van Menado, in 1853, Tijdschrift voor de Taal-, Landen Volkenkunde van Nederlandsch-Indië 10: 221258.

Kartasubrata, J., S.S. Tjitrosomo and R.C. Umaly (eds.) (1990) Symposium on agroforestry systems and technologies: Bogor, Indonesia, 19-21 September, 1989. Bogor: SEAMEO BIOTROP.

Kartomo, W. (1993) Indonesia: Stresses and reactions, in G.D. Ness, W.D. Drake and S.R. Brechin (eds.), Population-environment dynamics: Ideas and observations. Ann Arbor: University of Michigan Press.

Kaudern, W. (1925) Structures and settlements in Central Celebes. Göteborg: Elanders Boktryckeri Aktiebolag.

Kaya, M., L. Kammesheidt and H.-J. Weidelt (2002) The forest garden system of Saparua island, Central Maluku, Indonesia, and its role in maintaining tree species diversity, Agroforestry Systems 54: 225-234.

Keesing, F.M. (1962) The ethnohistory of northern Luzon. Stanford: Stanford University Press.

Kirch, P.V. (1994) The wet and the dry: Irrigation and agricultural intensification in Polynesia. Chicago: The University of Chicago Press.

Knaap, G.J. (1987) Kruidnagelen en Christenen: De Verenigde Oost-Indische Compagnie en de bevolking van Ambon 1656-1696. Dordrecht: Foris.

Knaap, G.J. (1995) The demography of Ambon in the seventeenth century: Evidence from colonial proto-censuses, Journal of Southeast Asian Studies 26: 227-241.

Knapen, H. (2001) Forests of fortune: The environmental history of Southeast Borneo, 1600-1800. Leiden: KITLV Press.

Koorders, S.H. (1898) Verslag eener botanische dienstreis door de Minahasa: Tevens eerste overzicht der flora van N.O. Celebes uit een wetenschappelijk en praktisch oogpunt. Batavia and 's-Gravenhage: G. Kolff.

Kruyt, A.C. (1895-1997) Een en ander aangaande het geestelijk en maatschappelijk leven van den PosoAlfoer, Mededeelingen van wege het Nederlandsch Zendelinggenootschap 39: 1-36(I), 106-128(II), 129153(III); 40: 121-160(IV); 41: 1-22(V), 23-42(VI), 42$52(\mathrm{VII})$.

Kruyt, A.C. (1899) Het stroomgebied van de Tomasa-rivier, Tijdschrift van het Koninklijk Nederlandsch Aardrijkskundig Genootschap 16: 593-618. 
Kruyt, A.C. (1901) Het ijzer in Midden-Celebes, Bijdragen tot de Taal-, Land- en Volkenkunde van NederlandschIndië 53: 148-160.

Kruyt, A.C. (1903) Gegevens voor het bevolkingsvraagstuk van een gedeelte van Midden-Celebes, Tijdschrift van het Koninklijk Nederlandsch Aardrijkskundig Genootschap 20: 190-205.

Kummer, D.M., R. Concepcion and B. Canizares (1994) Environmental degradation in the uplands of Cebu, The Geographical Review 84: 266-276.

Leach, H.M. (1999) Intensification in the Pacific: A critique of the archaeological criteria and their application, Current Anthropology 40: 311-339.

Levang, P. (1997) La terre d'en face: La transmigration en Indonésie. Paris: Éditions de l'Orstom.

Lewis, M.W. (1992) Wagering the land: Ritual, capital, and environmental degradation in the Cordillera of northern Luzon, 1900-1986. Berkeley: University of California Press.

Lindert, P.H. (2000) Shifting ground: The changing agricultural soils of China and Indonesia. Cambridge, MA: MIT Press.

Löffler, E. (1982) Übersichtsuntersuchungen zur Erfassung von Landresourcen in West-Kalimantan, Indonesien, in E. Meynen and E. Plewe (eds.), Forschungsbeiträge zur Landeskunde Süd- und Südostasiens: Festschrift für Harald Uhlig zu seinem 60. Geburtstag. Wiesbaden: Franz Steiner.

Mabbett, I.W. (1977) The 'Indianization' of Southeast Asia: Reflections on the prehistoric sources, Journal of Southeast Asian Studies 8: 1-14.

Mai, U. and H. Buchholt (1987) Peasant pedlars and professional traders: Subsistence trade and rural markets in Minahasa, Indonesia. Singapore: Institute of Southeast Asian Studies.

Malthus, T.R. (1976) An essay on the principle of population. New York: W.W. Norton. (First published 1798.)

Matthes, P.A. (1881) Memorie van overgave van de residentie Menado. (NA MvO MMK 300)

Metzner, J.K. (1982) Agriculture and population pressure in Sikka, Isle of Flores: A contribution to the study of agricultural systems in the wet and dry tropics. Canberra: Development Studies Centre, Australian National University.

Michon, G. and H. De Foresta (1995) The Indonesian agroforest model: Forest resource management and biodiversity conservation, in P. Halladay and D.A. Gilmour (eds.), Conserving biodiversity outside protected areas: The role of traditional agro-ecosystems. Gland, Switzerland: International Union for the Conservation of Nature and Natural Resources.

Mohr, E.C.J. (1938a) Climate and soil in the Netherlands Indies, Bulletin of the Colonial Institute of Amsterdam 1: 241-251.

Mohr, E.C.J. (1938b) The relationship between soil and population density in the Netherlands East Indies, in Comptes Rendus du Congrès International de Géographie Amsterdam 1938, Vol. 2, Géographie Coloniale. Leiden: E.J. Brill.

Netting, R.McC. (1993) Smallholders, householders: Farm families and the ecology of intensive, sustainable agriculture. Stanford, CA: Stanford University Press.
Nibbering, J.W. (1991) Crisis and resilience in upland land use in Java, in J. Hardjono (ed.), Indonesia: Resources, ecology, and environment. Singapore: Oxford University Press.

Nibbering, J.W. (1997) Upland cultivation and soil conservation in limestone regions on Java's south coast: Three historical case studies, in P. Boomgaard, F. Colombijn and D. Henley (eds.), Paper landscapes: Explorations in the environmental history of Indonesia. Leiden: KITLV Press.

Nibbering, J.W. (1999) Tree planting on deforested farmlands, Sewu Hills, Java, Indonesia: Impact of economic and institutional changes, Agroforestry Systems 46: 6582.

Olivier, J. (1834-1837) Reizen in den Molukschen archipel naar Makassar, enz. in het gevolg van den gouverneurgeneraal van Nederland's Indië, in 1824 gedaan, 2 vols. Amsterdam: G.J.A. Beijerinck.

Ormeling, F.J. (1955) The Timor problem: A geographical interpretation of an underdeveloped island. Djakarta: J.B. Wolters.

Padoch, C. (1985) Labour efficiency and intensity of land use in rice production: An example from Kalimantan, Human Ecology 13: 271-289.

Palte, J.G.L. (1989) Upland farming on Java, Indonesia: A socio-economic study of upland agriculture and subsistence under population pressure. PhD thesis, University of Utrecht. Amsterdam: Koninklijk Nederlands Aardrijkskundig Genootschap.

Pelzer, K.J. (1945) Pioneer settlement in the Asiatic tropics: Studies in land utilization and agricultural colonization in Southeastern Asia. New York: American Geographical Society.

Pelzer, K.J. (1963) The agricultural foundation, in R. McVey (ed.), Indonesia. New Haven, CT: Yale University Press.

Platteau, J.-P. (2000) Institutions, social norms, and economic development. Amsterdam: Harwood Academic.

Potter, L. (2001) Agricultural intensification in Indonesia: Outside pressures and indigenous strategies, Asia Pacific Viewpoint 42: 305-324.

Ptak, R. (1992) The northern trade route to the spice islands: South China Sea-Sulu Zone-North Moluccas (14th to early 16th century), Archipel 43: 27-55.

Reid, A. (1988-1993) Southeast Asia in the age of commerce, 1450-1680, 2 vols. New Haven, CT: Yale University Press.

Reid, A. (1995) Humans and forests in pre-colonial Southeast Asia, Environment and History 1: 93-110.

Reid, A. (2001) South-East Asian population history and the colonial impact, in Ts'ui-jung Liu, J. Lee, D.S. Reher, O. Saito and Wang Feng (eds.), Asian population history. Oxford: Oxford University Press.

Reinwardt, C.J.C. (1858) Reis naar het oostelijk gedeelte van den Indischen Archipel, in het jaar 1821. Amsterdam: Frederik Muller.

Repetto, R. (1986) Soil loss and population pressure on Java, Ambio 15: 14-18.

RePPProT (Regional Physical Planning Programme for Transmigration) (1990) The land resources of Indonesia: A national overview, 2 vols (text, atlas). Jakarta: Government of the Republic of Indonesia/Overseas 
Development Administration, Foreign and Commonwealth Office, UK.

Rigg, J. (1986) Innovation and intensification in northeastern Thailand: Brookfield applied, Pacific Viewpoint 27(1): 29-45.

Rigg, J. (1991) Southeast Asia: A region in transition. A thematic human geography of the ASEAN region. London: Unwin Hyman.

Rigg, J. (1997) Southeast Asia: The human landscape of modernization and development. London: Routledge.

Robequain, C. (1946) Le Monde Malais: Péninsule malaise, Sumatra, Java, Bornéo, Célèbes, Bali et les Petites lles de la Sonde, Moluques, Philippines. Paris: Payot.

Robson, S. (ed.) (1995) Desawarnana (Nagarakrtagama) by Mpu Prapanca. Leiden: KITLV Press.

Salafsky, N. (1995) Forest gardens in the Gunung Palung region of West Kalimantan, Indonesia: Defining a locallydeveloped, market-oriented agroforestry system. Agroforestry Systems 28: 237-268.

Scholz, U. (1984) Ist die Agrarproduktion der Tropen ökologisch benachteiligt? Überlegungen am Beispiel der dauerfeuchten Tropen Asiens, Geographische Rundschau 36: 360-366.

Scholz, U. (1988) Agrargeographie von Sumatra. Giessen: Selbstverlag des Geographischen Instituts der Justus Liebig, Universität Giessen.

Scholz, U. (1991) Überlegungen zum Agrarpotential und zur Tragfähigkeit tropischer Regenwaldgebiete, in $\mathrm{U}$. Scholz (ed.), Tropischer Regenwald als Ökosystem. Giessen: Wissenschaftliches Zentrum Tropeninstitut Giessen.

Schouten, M.J.C. (1998) Leadership and social mobility in a Southeast Asian society: Minahasa, 1677-1983. Leiden: KITLV Press.

Schrauwers, A. (2000) Colonial 'reformation' in the highlands of Central Sulawesi, Indonesia, 1892-1995. Toronto: University of Toronto Press.

Seavoy, R.E. (1973) The transition to continuous rice cultivation in Kalimantan, Annals of the Association of American Geographers 63: 218-225.

Seavoy, R.E. (1980) Population pressure and land use change: From tree crops to sawah in Northeastern Kalimantan, Indonesia, Singapore Journal of Tropical Geography 1(2): 61-67.

Sinclair, F.L. (1999) A general classification of agroforestry practice, Agroforestry Systems 46: 161-180.

Smiet, A.C. (1990) Agro-forestry and fuel-wood in Java, Environmental Conservation 17: 235-238.

Spencer, J.E. (1966) Shifting cultivation in Southeastern Asia. Berkeley: University of California Press.

Stargardt, J. (1992) Water for courts or countryside: Archaeological evidence from Burma and Thailand reviewed, in J. Rigg (ed.), The gift of water: Water management, cosmology and the state in South East Asia. London: School of Oriental and African Studies.

Steller, E. (1866) De Sangi-archipel. Amsterdam: H. de Hoogh.

Steup, F.K.M. (1931) Bijdragen tot de kennis der bosschen van Noord- en Midden Celebes II. Een verkenningstocht door Midden-Celebes, Tectona 24: 11211135 .
Stone, G.D. (2001) Theory of the square chicken: Advances in agricultural intensification theory, Asia Pacific Viewpoint 42: 163-180.

Stoney, C. and M. Bratamihardja (1990) Identifying appropriate agroforestry technologies in Java, in M. Poffenberger (ed.), Keepers of the forest: Land management alternatives in Southeast Asia. West Hartford, CT: Kumarian Press.

Tammes, P.M.L. (1936) De cultuur van een weinig bekende palm voor sago-winning op Sangihe, Landbouw 12: 43-49.

Tammes, P.M.L. (1940) De biologische achtergrond van het bevolkingsvraagstuk op Noord-Celebes en de Sangiheen Talaud-archipel, Tijdschrift voor Economische Geographie 31: 177-198.

Tammes, P.M.L. (1949) De bevolkingscultuur van klapper in het bijzonder in Oost Indonesië. (Mededelingen van het Departement van Economische Zaken in Nederlandsch-Indië 11.)

Tergast, G.C.W.C. (1936) Schets van den landbouw op de Sangihe- en Talaud-eilanden, Landbouw 11: 125145.

Terra, G.J.A. (1958) Farm systems in South-East Asia, Netherlands Journal of Agricultural Science 6: 157-182.

Teysmann, J.E. (1861) Verslag van den honorair-inspecteur van kultures J.E. Teysmann, over de door Z.Ed. in 1860 gedane reize in de Molukken, Natuurkundig Tijdschrift voor Nederlandsch-Indië 23: 290-369.

Tiffen, M. (1995) Population density, economic growth and societies in transition: Boserup reconsidered in a Kenyan case-study, Development and Change 26: 3166.

Tiffen, M. (1996) Land and capital: Blind spots in the study of the 'resource-poor' farmer, in M. Leach and R. Mearns (eds.), The lie of the land: Challenging received wisdom on the African environment. London: The International African Institute.

Tiffen, M. and M. Mortimore (1994) Malthus controverted: The role of capital and technology in growth and environment recovery in Kenya, World Development 22: 997-1010.

Tiffen, M., M. Mortimore and F. Gichuki (1994) More people, less erosion: Environmental recovery in Kenya. Chichester: Wiley.

Uhlig, H. (1984) Reisbauökosysteme mit künstlicher bewässerung und mit pluvialer Wasserzufuhr: Java und analoge Typen im übrigen Südostasien, Erdkunde 38: 16-29.

Uhlig, H. (1995) Bevölkerungsdruck, Landnot und der Ausbau der Landnutzung in Indonesien (besonders auf Java), in S. Wälty and B. Werlen (eds.), Kulturen und Raum: Theoretische Ansätze und empirische Kulturforschung in Indonesien. Festschrift für Professor Albert Leemann. Zürich: Rüegger.

Van Beukering, J.A. (1947) Het ladangvraagstuk: Een bedrijfs- en sociaal economisch probleem. Batavia: Departement van Economische Zaken. [Mededeelingen van het Departement van Economische Zaken in Nederlandsch-Indië 9.]

Van Delden, A.J. (1844) De Sangir-eilanden in 1825, Indisch Magazijn 1(4-6): 356-383; 1(7-9): 1-32. 
Van De Velde Van Cappellen, D. (1857) Verslag eener bezoekreis naar de Sangi-eilanden, Mededeelingen van wege het Nederlandsch Zendelinggenootschap 1: 2783.

Van der Aa, R. (ed.) (1867) Het journaal van Padtbrugge's reis naar Noord-Celebes en de Noordereilanden. (16 Aug.-23 Dec. 1677.), Bijdragen tot de Taal-, Land-en Volkenkunde van Nederlandsch-Indië 14: 105-565.

Van Dinter, B.C.A.J. (1899) Eenige geographische en ethnographische aanteekeningen betreffende het eiland Siaoe, Tijdschrift voor Indische Taal-, Land- en Volkenkunde 41: 324-389.

Van Doren, J.B.J. (1857-1860) Herinneringen en schetsen van Nederlands Oost-Indië, 2 vols. Amsterdam: J.D. Sybrandi.

Van Hoëvell Baron, G.W.W.C. (1893) Todjo, Posso en Saoesoe, Tijdschrift voor Indische Taal-, Land- en Volkenkunde 35: 1-47.

Van Marle, V.J. (1922) Verslag eener spoorwegverkenning in de afdeeling Menado, 2 vols. Weltevreden: Landsdrukkerij.
Van Rhijn, M. (1941) Memorie van overgave van de residentie Menado. (KITLV H1179)

Van Steenis, C.G.G.J. (1937) De invloed van den mensch op het bosch, Tectona 30: 634-653.

Volkstelling 1930 (1933-1936) Batavia: Departement van Economische Zaken (8 vols).

Wander, H. (1965) Die Beziehung zwischen Bevölkerungs- und Wirtschaftsentwicklung, dargestellt am Beispiel Indonesiens. Tübingen: J.C.B. Mohr.

Wilken, N.P. (1870) lets over den landbouw in de Minahassa en de daarbij gebruikelijke benamingen, Tijdschrift voor Nederlandsch Indië 4(2): 373385.

Wilken, N.P. and J.A. Schwarz (1867) Allerlei over het land en volk van Bolaäng Mongondou, Mededeelingen van wege het Nederlandsch Zendelinggenootschap 11: 284-398.

Zimmermann, G.R. (1992) Die Besiedlung Südostasiens: Eine ethno-ökologische Perspektive. Nackenheim: Privately published. 